For example, the city of Guiyang in China introduced severe restrictions on termination of pregnancy after 14 weeks and women now need a special letter of authorization from local authorities before they can obtain an abortion (Reprod Health Matters 2008; 16:90-98).

It's also become commonplace for providers in India to self-restrict their practices to the first trimester in order to ensure they can't be accused of providing sex-selective abortions (Econ Polit Wkly 2004;39:5044-52).

South Korea is the only country that has achieved a reduction in imbalanced sex ratios at least in part because of sex selection prohibitions. But the reduction in discrimination is also in part the product of social and economic change, as well as a "Love Your Daughters" media campaign, according to the United Nations Population Fund (www.unfpa.org/gender/docs /studies/summaries/regional_analysis .pdf).

Franks argues that relying on targeted public awareness and education campaigns, without prohibiting sexselective abortion, is the equivalent of endorsing the practice.

And waiting for broad social change won't provide immediate protection for a woman currently being coerced into aborting a female fetus, he adds. "[Criminalizing sex-selective abortion] would give her the private right of action to defend herself against this coercion. If there's anything uglier than aborting a child because of its color or sex, it would be being forced to do that." - Lauren Vogel, CMAJ

CMAJ 2012. DOI:10.1503/cmaj.109-4097

Second of a two-part series.

Part I: Sex selection migrates to

Canada (www.cmaj.ca/lookup/doi /10.1503/cmaj.109-4091).

\title{
Utility, stability and a digital presence
}

$\mathrm{T}$ he first person Dr. John Fletcher shared the good news with was a flight attendant. Sitting alone in the international departures lounge of an airport, en route to his sister-in-law's wedding, he had no friends or family nearby when he received the call offering him the job as $C M A J$ 's new Editor-in-Chief.

"I felt excited and a sense of responsibility, in equal measure. This is a big job," says Fletcher, a native of Cheshire, England, who received his medical degree from the University of Cambridge in the United Kingdom and a master's degree in public health from Harvard University in Cambridge, Massachusetts.

He takes over the leadership of the journal from Dr. Rajendra Kale, interim Editor-in-Chief since Oct. 1, 2011 (www.cmaj.ca/lookup/doi/10.1503/cmaj .109-4025). Fletcher was chosen as the 17th Editor-in-chief (there have also been two interim Editors-in-chief) by an eight-member selection committee appointed to find a replacement for former Editor-in-Chief Dr. Paul Hébert. Before accepting a position as deputy editor (research) at $C M A J$ three years ago, Fletcher worked for seven years as an editor at $B M J$.

"We are very pleased that John Fletcher has taken on this key role," CMA President Dr. John Haggie stated in a press release. "His wide experi-

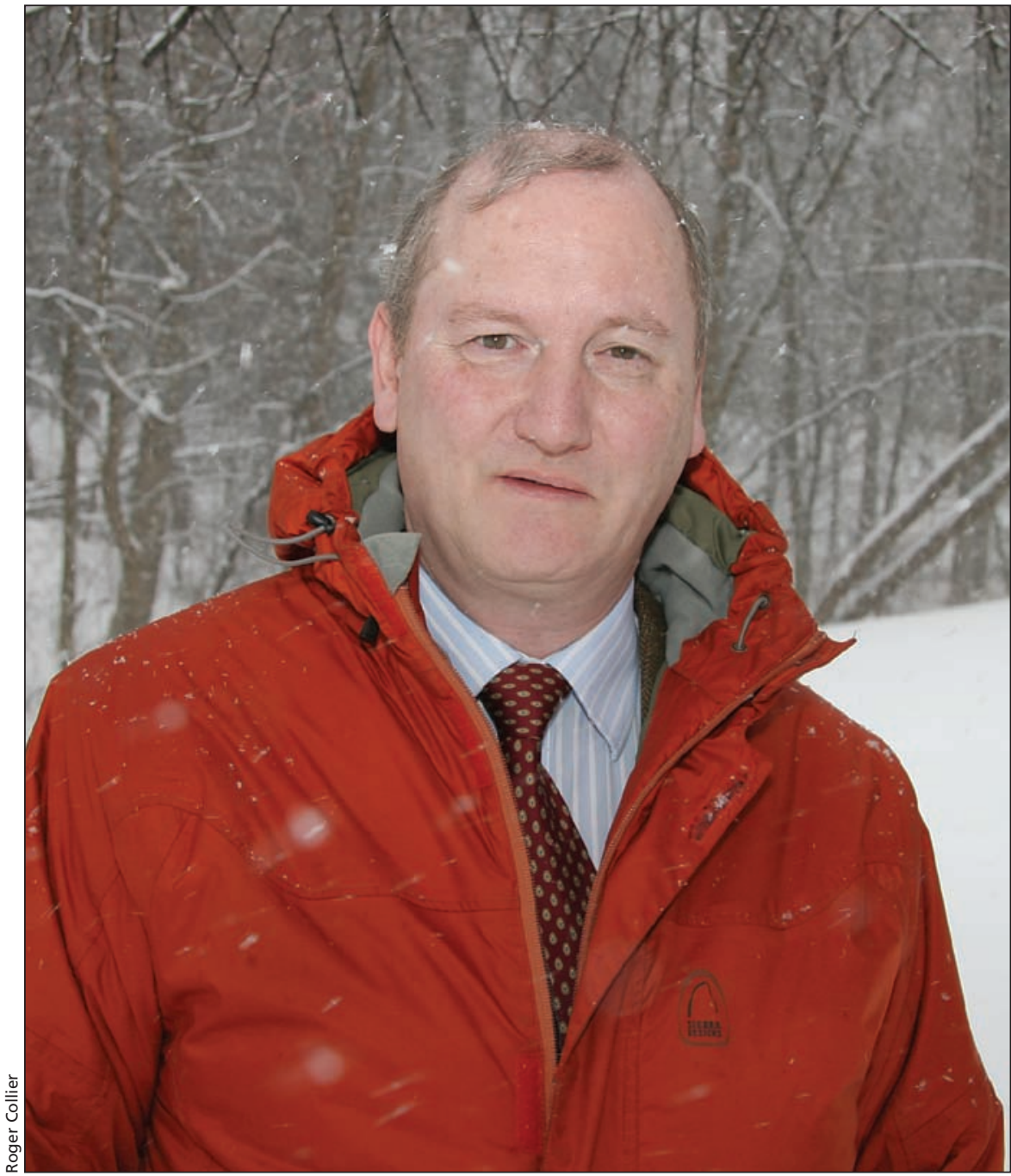

"I felt excited and a sense of responsibility, in equal measure. This is a big job," says newly appointed CMAJ Editor-in-Chief Dr. John Fletcher. 
ence in medical research, writing and editing, as well has his clinical and business background, have already proven to be a great asset to the journal. I am confident he will inspire CMAJ staff and help drive the journal's reputation as a standard-bearer for medical knowledge as it heads into its second century."

"John Fletcher has the right combination of leadership and interpersonal skills, editorial expertise and a commitment to knowledge transfer," added CMA Secretary General and CEO Paul-Émile Cloutier. "I think he will be an excellent editor-in-chief."

Fletcher has three goals in mind for $C M A J$. He would like to see the journal improve its digital presence, attain financial stability and become more useful to practising physicians.

"The particular vision for content that I have is to focus more on the needs of Canadian doctors. That doesn't mean we are going to take our eyes off of research, but the practice section of the journal is the part aimed at practising doctors," says Fletcher. "I want to focus on medical topics and clinical cases that are relevant to the most readers."

As for the business side of putting out a medical journal, Fletcher acknowledges that the past few years have been tough. Although CMAJ garnered roughly $\$ 13$ million in profits for CMA over the course of two decades leading up to 2008, it required contributions from the association in recent years to allay the effects of declining advertising revenues (www.cmaj.ca /lookup/doi/10.1503/cmaj.109-3356).

Fletcher plans to help put the journal back on firm financial ground. "I'm going to focus on maximizing the revenue of the journal and reducing our expenses. It is very important for the journal to be financially sound."

His third priority will be to establish a clearer distinction between print and digital versions of the journal. Currently, they're similar, with the website primarily serving as a means to archive content or release it prior to print says Fletcher, who envisions the print edition of the journal becoming shorter, easier to read and used to highlight content on CMAJ's website, which would be expanded to include blogs, reader surveys and social media.

"The website could become a meeting place for our readers," says Fletcher. "It could be a place where they discuss what is being read."

When he can turn his mind from improvements to the journal, Fletcher can sometimes be found with his wife, Alison, and children William, Louisa and Charlotte on hiking trails in Ottawa, Ontario, or just across the river in the hills of Gatineau Park, Quebec, enjoying the wildlife. "In the UK, you can't get within a quartermile of a rabbit or deer. Here, you can put out your hand and feed a bird. It's stunning," says Fletcher, adding that he was introduced to canoeing and wilderness camping last summer. "I'm now planning another trip." - Roger Collier, CMAJ

CMAJ 2012. DOI:10.1503/cmaj.109-4096

\section{More news online}

Sex selection migrates to Canada: Easy access to abortion and advances in prenatal sex determination have combined to make Canada a haven for parents who would terminate female fetuses in favour of having sons, despite overwhelming censure of the practice, economists and bioethics experts say (www.cmaj.ca/lookup/doi/10.1503/cmaj.109-4091). — Lauren Vogel, CMAJ

Online drug shortage registry "limited" in application: An online registry of current and impending drug shortages has been launched (www.cmaj.ca/lookup/doi/10.1503/cmaj.109-4100). — Lauren Vogel, CMAJ

Much ado about $\mathbf{\$ 1 0 0}$ million: An informal survey indicates that Canada's major hospitals generate only about $\$ 100$ million in gross revenues per year from parking fees (www.cmaj.ca/lookup/doi/10.1503 /cmaj.109-4095). - Kayla Redstone, Ottawa, Ont.

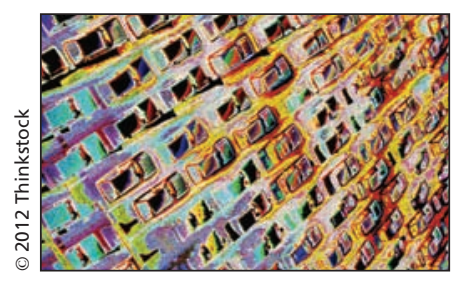

Discount deals becoming a medical rage: In the brave new worlds of Internet advertising and collective Internet buying, discounts can be found for everything from hair transplants to "detox foot pads" (www.cmaj.ca/lookup /doi/10.1503/cmaj.109-4089). — Julia Sisler, Ottawa, Ont.

Europe overhauls physician mobility regulations: Alerts about fitness to practice sanctions and a "professional card" for doctors are among measures proposed for Europe (www.cmaj.ca/lookup/doi/10.1503/cmaj.109-4106). — Tiago Villanueva MD, Lisbon, Portugal

Policy lens to focus integration of home care under development: The Canadian Home Care Association is drafting a national framework to outline the role of home care within the health care system (www.cmaj.ca/lookup /doi/10.1503/cmaj.109-4110). — Lauren Vogel, CMAJ

World Health Organization reform languishes: Observers say they'd like to finally see a bit of decision-making about proposed financing and governance reforms at the World Health Organization (www.cmaj.ca/lookup /doi/10.1503/cmaj.109-4111). — Roger Collier, CMAJ

CMAJ 2012. DOI:10.1503/cmaj.109-4107 cmaj.ca 